\title{
Ethical Implications of Public Relations in Bangladesh: Islamic Perspective
}

\author{
Md. Shariful Haque ${ }^{1}$, Syeda Tanjila Shahnewaz ${ }^{2}$, Md. Noman Siddikee ${ }^{3}$ \\ ${ }^{1}$ Assistant Professor, Department of Business Administration, International Islamic University Chittagong, Bangladesh \\ ${ }^{2}$ Lecturer, School of Business Studies, Southeast University, Bangladesh \\ ${ }^{3}$ Department of Business Administration, International Islamic University Chittagong, Bangladesh
}

\begin{abstract}
This paper aims to examine public relation practices in Bangladesh, weighing its ethical implications from an Islamic perspective and investigates whether it comply with Islam's ethical specifications to facilitate Muslim Marketer's thoughts and practices. The paper uses Qur'an (Chapter 3, Verse 103) as a theoretical framework to critically evaluate relevant information to ascertain the extent of ethical legitimacy of promotional strategies used in public relations in Bangladesh. It cites relevant references from Qur'an and Sunnãh as interpretive evidences and methodology. Islam puts stress on institutionalizing ethics in every aspects of Business. This complete code of life strongly recommends Muslims to do business which should certainly be in the ethical framework guided by Shari'ah. The existing public relation strategies in Bangladesh are ethically dubious. Undue influence, exertion of too much political power, flattering, fabrication, falsehood, and bribery are very much common practices done by the corporations to build favorable public relations. No ways are these in compliance with Islamic Ethical Values. This paper suggests the necessity for further research into the ethical dimensions of business practices in Bangladesh to promote ethical awareness in the society. This study includes mutual socio-economic and ethical responsibilities among Bangladeshi Marketers to save the society from corruption and moral deterioration.
\end{abstract}

Key Words: Ethics, Bangladesh, Promotional Strategies, Public Relations, Shari'ah JEL Classification Code: M10, M30

\section{INTRODUCTION}

$\mathrm{E}$ thics has become a buzz word in today's business environment. Corporations are getting concerned about Corporate Governance, Corporate Social Responsibility, Green Marketing etc. But none of them can substitute ethical behavior completely. There are a good number of papers authored on Business Ethics. But a few papers have been penned relating to Promotional Mix elements from Islamic perspective. In this paper the researcher engaged his efforts to make up the gap. Jibrail Bin Yusuf authored a paper on 'Ethical implications of sales promotion in Ghana: Islamic Perspective' in 2010. That paper inspired this author to work on another Promotional Mix element - Public Relation from Islamic Perspective. This work investigated the present practices of Public Relation in Bangladeshi corporations and examined their compliance with Islamic Ethical Values. This paper will shed light of Islamic Ethics on the minds of Muslim managers so that they can pull off their goals herein and hereafter [Hasanah fil Dunia wa fil A'khirah].

\section{Theoretical OVERVIEW AND Literature REVIEW}

Ethical issues are important for an effective organization and are essential for good interpersonal relations and Muslim managers must stick to the Islamic Code of Ethics (Abuznaid, 2009) ${ }^{[1]}$. Ethics is a branch of moral philosophy that deals with moral behavior. Morality refers to an ability

to judge what is good or bad, right or wrong. Morality is a complex concept which can be defined in terms of both means and ends. Means indicate process that occurs and Ends refers to the consequences (Cherrington and Cherrington, 1995) ${ }^{[2]}$. Yusuf (2010) ${ }^{[3]}$ worked on the Ethical implication of sales promotion in Ghana where he showed the dimensions of sales promotion and their compliance with Islamic code of Ethics. Qur'an - The Divine Book guides Muslims how to make relationship each other. In Islam the sign of relationship is 'Brotherhood'. Brotherhood is for the satisfaction of Allah (SWT). The sense has been portrayed in the Qur'an, Chapter 3, verse 103. Here Allah (SWT) has said: 'And hold firmly to the rope of Allah all together and do not become divided. And remember the favor of Allah upon you when you were enemies and He brought your hearts together and you become, by His favor, brothers. And you were on the edge of a pit of fire, and He saved you from it. Thus does Allah make clear to you His verses that you may be guided (3:103). It also gives the hints of Unity among the Muslims - the unity is not superficial or ornamental. This unity is the unity of hearts of believers. Islam doesn't permit the artificial relations or unity which is for the mere worldly interest or benefit. Artificial relationship does not persist. The material unity only can be the source of division and selfishness. Islam has set up the superstructure of relationship and unity on Faith, Love, and Sacrifice for each other (Murad, 2003) ${ }^{[4]}$. Thus it is possible to construct a welfare society where cooperation and patronization substitute disputes and conflicts. In this 
enlightened society the 'Eat or Be Eaten' slogan doesn't work. Only the 'pull' or 'push' theory works. Pulling the deprived ones at a better position and pushing rich one's wealth to the deprived ones are the senses. In the Qur'an it has been said: 'If you disclose your charitable expenditures, they are good; but if you conceal them and give them to the poor, it is better for you, and He will remove from you some of your misdeeds [thereby]. And Allah, with what you do, is [fully] Acquainted (Chapter 2, Verse 271).' It has also said: 'O you who have believed, do not consume one another's wealth unjustly but only [in lawful] business by mutual consent (Chapter 4, Verse 29).'

\section{Traditional View of Public Relation}

In Marketing it is said that marketers do not sell products, they offer a complete marketing mix before the buyers. Kotler \& Keller (2005) ${ }^{[5]}$ showed Marketing Mix as a collection of Ps -4 Ps, 7Ps, or 8Ps. Subsequently these 4Ps have become $4 \mathrm{Cs}$ as considered from Buyer's viewpoints. One of these Ps is 'Promotion' which corresponds to the 'Communication' from Cs. Promotion/communication has a separate mix called Promotion/Communication Mix. Public Relation is one of the significant elements in the Promotion/Communication Mix. Public relation has been defined as building good relations with the company's various publics by obtaining favorable publicity, building up a good corporate image and handling or heading off unfavorable rumors, stories, and events (Kotler, et al., 2011) ${ }^{[6]}$. Figure -1 shows a snapshot of communication Mix.

Publics are of different types - General Public, Local Public, Citizen-action Public, Government Public, Media Public, Financial Public and Internal Public (Kotler, et al., 2011) ${ }^{[7]}$. Companies make the relationships with these publics so that they can remain safe from unfavorable rumors and stories against them.

In marketing the attitude of General publics of a target area is important. In Bangladesh the perception of general publics about wine is not positive. So marketers can't produce and sell wine conveniently in this market. Due to this public attitude Government restrict the production and impose heavy duty on its' sale in Bangladesh. Consumer organizations or environmental concerned groups are Citizen-action public frequently raises voice on different issues and build a strong wall against Marketers. For this reason Bangladeshi government was bound to pass a bill (Use and Production of Polythene Bags Act, 2002) in the parliament against production and use of polythene bags. Still this act is far behind the implementation due to the reluctance of managerial, technical and financial resources and the law enforcement agencies of government (Jahan, $2012)^{[8]}$. Local publics - neighborhood residents and community organizations play a significant role in the company's operations. If they create obstacles it becomes tough for the factories to run. Universities in the residential areas may disturb the harmony of resident's life in that area.
Factories waste chemical disturb the agriculture or cultivation of a certain area. In this case organizations need to be much caring to the local community. Corporations always remain tensed to convince Government public - government/ruling political parties and its' agencies to conduct an uninterrupted operation in a particular country or state. Government set the policies for corporations. Now it is observed in most of the countries including United States the large corporations work as patrons during the National Elections and decide which party should be in the power. This is an open secret. Accordingly the government also creates a facilitated environment for corporations they favor to run their activities.

Figure - 1: A Snapshot of Public Relation in Marketing Mix

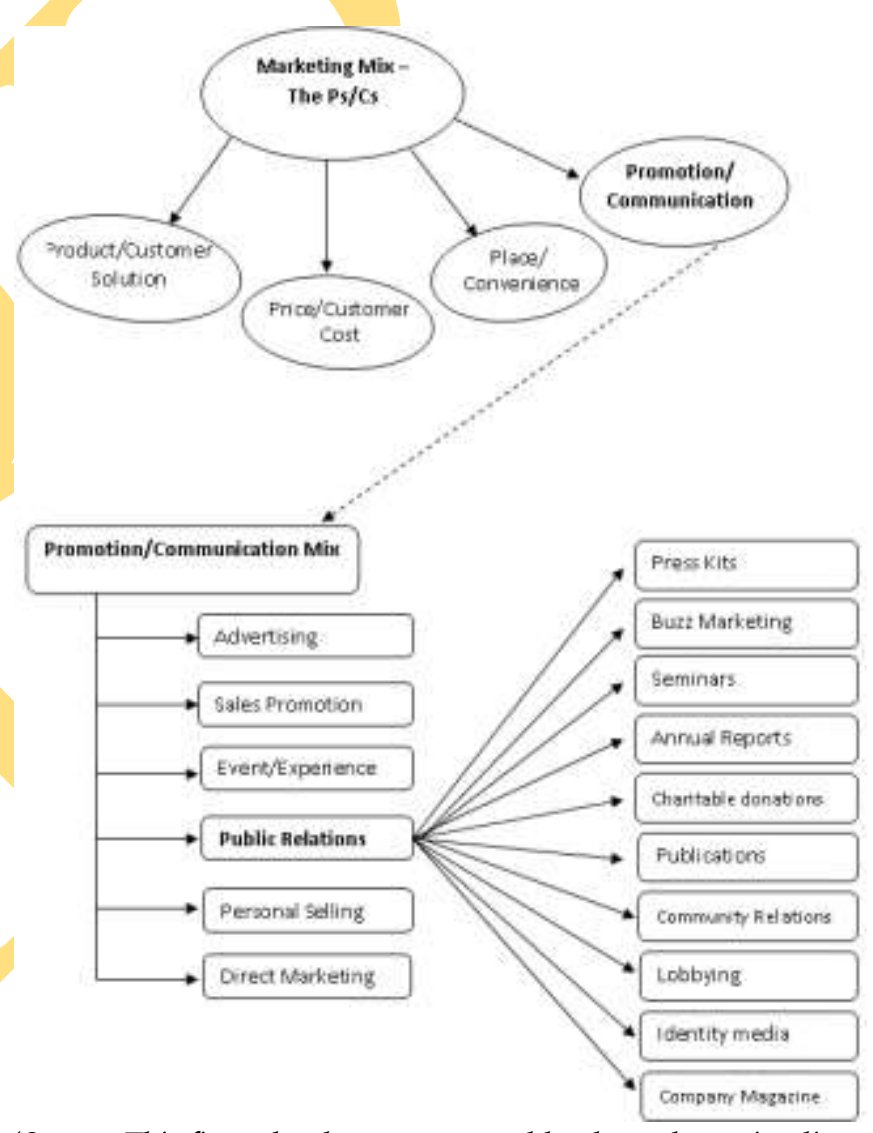

(Source: This figure has been constructed by the author using literatures of different Marketing Books.)

Among other publics, Financial public - Banks, Shareholders, Insurance companies, Investment houses and Media public - Television, Internet, Magazine, Newspaper play pivotal roles in company's activities. Financial publics supply the fund - treated as blood in an organization. Media publics appreciate the company's welfare activities and criticize tracing out the loopholes of companies.

Every medium or large scale enterprise is required to have a Public Relation (PR) cell or department with the appointment of public relation officers and staffs. In the figure -1 it has been shown how PR works. As shown in the figure speeches for product and commodity publicity, spe- 
cial events, buzz marketing, written materials, corporate identity materials, public service activities, social networking, and a company's website are the important PR vehicles. For a long time Advertising - the peer of PR is being appreciated for its' undisputed contribution in Brand building. But recently Marketing consultants are proclaiming the dominance of PR over advertising for building a strong brand. The Ries (2002) ${ }^{[9]}$ sisters wrote: 'The birth of a brand is usually accomplished with [Public Relations], not advertising'.

\section{Scenario of Public Relation Practices in BANGLADESH}

Bangladesh is a Muslim majority (Muslim $89.5 \%$, Hindu $9.6 \%$, Others $0.9 \%$ ) country the total population of which is $161,083,804$ as of July 26,2012 according to CIA World Factbook. Government of this country runs with Parliamentary Democracy (www.indexmundi.com, 2012) ${ }^{[10]}$. It has got its independence on $26^{\text {th }}$ March 1971 from Pakistan. Around 15 years it was ruled by the Military due to the dispute of political parties. Around 10 Political parties contribute significantly in the formation of Government. But two major parties Bangladesh Awami League and Bangladesh Nationalist Party are dominating.

Bangladesh economy has been growing $5-6 \%$ per year since 1996 even though there are many constraints like political instability, corruption, pitiable infrastructure, inadequate power supplies, and sluggish implementation of economic reforms. More than half of GDP is generated through the service sector, $45 \%$ of Bangladeshis are employed in the agriculture sector with rice as the singlemost-important product. Garment exports, totaling \$12.3 billion in FY09 and remittances from overseas Bangladeshis, totaling $\$ 11$ billion in FY10, accounted for almost $12 \%$ of GDP (www.indexmundi.com, 2012).

Readymade Garment (RMG) sector contributes a lot in the country economy. Bhattacharya (2002) ${ }^{[1]}$ shown the total manufacturing sector's contribution to GDP was about $15.6 \%$ when RMG sector contributed about $29.7 \%$ of the manufacturing GDP in FY 2002. In the same year this sector contributed $76.6 \%$ of the total Bangladesh export. This sector has employed 1.8 million workers where 1.5 million are women. They do not have much literacy. So they can be easily exploited. There are substantial violations of laws and labor policies. There had been, in fact, no answerability or enforceability. But because of the interventions of Human rights agencies, international buyers, and some international agencies like UNICEF and ILO the condition is a bit better (Mahmud and Kabeer, 2006) ${ }^{[12]}$. In public relation there was another kind of publics like internal public. This is the scenario of making an unfavorable relation with internal publics.

Bangladesh has a record number of companies and in many of them have the public relation practices. Besides the conventional ventures some Islamic organizations are also keeping their successful steps in the country business. Here, in this paper, the author wanted to show whether Bangladeshi companies are in compliance with ethical values set by Islam. In this connection the cases relating to public relation of some selected companies has been described.

Chevron is an American multinational corporation which is engaged in every aspect of the oil, gas and geothermal energy industries. It has the biggest ever Foreign Direct Investment in Bangladesh as it has committed to invest around \$1billion to raise output from Bibiyana Gas field. As reported by bdnews24.com on 30 July 2012, the CEO of Chevron Geoff Strong said, "This project will provide more affordable energy that will not only increase Chevron's business in Bangladesh but also help drive economic growth and alleviate poverty for many millions of people". Chevron was committed to consider the community people who lost their lands and were suffering from the effect of Gas field as partners to share goals and mutual respect and cooperation. But the reality was different. Gardner (2012) ${ }^{[13]}$ conducted a research involving the villagers of two neighboring villages when the majority spoke of their fears of corruption, environmental damage and their sense of injustice at the profits made by foreign multinationals exploiting local resources. Research findings of Katy Gardner were surprising. Chevron promised to invest in health, education and alternative livelihoods projects as part of their Community Engagement Programme. It wanted to empower people (Local Public) as part of their Public relation program. Chevron promised to hear the community peoples' concern on different issues related to the project. But Chevron heard a little the concern of the poor. Initially there were 'community consultation meetings', once the land acquisition process was complete, community liaison staff retreated behind the high wire fence of the enclave and only the elite leaders had any means of contacting them. There were no grievance procedures and no open meetings. Whilst the company did respond to farmers' complaints of damage to the environment, they acted without consulting the farmers. The main issue was the installation's high banked roads, which prevent water from flowing evenly over rice fields during the wet season. Chevron built culverts in the roads, but these were very small and became blocked with weeds. A year later, no further action had been taken.

Recently Anti Corruption Commission (ACC) of Bangladesh filed a suit against a Company Hallmark for taking loan of a substantial amount in an undue way. The Bangladesh Bank - the Central Bank of Bangladesh investigated and found that one of the branches (Ruposhi Bangla Hotel branch) of Sonali Bank (A Public Owned Bank) lent Hallmark Group (Not much renowned group) and five other companies Tk 3,547 crore (equals to 0.436 billion USD) between 2010 and May, 2012 on fake documents. The businesses embezzled the whole amount that belongs to depositors in collusion with some bank officials. Of Tk 3,547 crore, 
Hallmark Group alone took away Tk 2,686.14 crore, T and Brothers Tk 609.69 crore, Paragon Group Tk 146.60 crore, Nakshi Knit Tk 66.36 crore, DN Sports Tk 33.25 crore and Khanjahan Ali Tk 4.96 crore. Of the six borrowers, Hallmark has been found to be the biggest fraudster.

On March 28 this year, Hallmark opened local letters of credit worth Tk 500 crore in favor of Anwara Spinning Mills, Max Spinning Mills and Star Spinning Mills to buy yarn. The three companies are also clients of the bank's same branch. Following Hallmark's guarantee to repay the LCs, the bank purchased the acceptance bills and disbursed the money to the accounts of the three spinning mills. A few days later, the three mills asked the bank branch to transfer the money to the account of Hallmark Group and the branch duly obliged. Later, Hallmark transferred the money to a current account of Century International, a concern of the group. (This report has been poised from a Bangladeshi national daily - The Daily Star, Tuesday, 14 August 2012 issue) ${ }^{[14]}$.

Construction of a bridge of $6.15 \mathrm{~km}$ long and $21.10 \mathrm{~m}$ wide on the river Padma is a mega project of Bangladesh Government. Project's estimated cost is 3.0 billion USD when ADB was supposed to fund USD 615m, World Bank USD 1.5 b, JICA USD 415m, IDB USD 140m, Abu Dhabi Development Group USD 30m, and government would finance 50 million BDT. But suddenly it was observed that World Bank the contributor of major portion objected and somewhat refused to finance the project. The reason was corruption. In a statement, the bank accused the government in Dhaka of failing to investigate claims of high-level fraud in connection with the project (bbc.co.uk, 30 June 2012) ${ }^{[15]}$. BBC also reported 'corruption allegations also involve two former executives from Canada's engineering company SNC-Lavalin. The company has been under investigation by Canada's prosecutors for more than a year, and the two executives now face charges of trying to bribe Bangladeshi officials. The Padma bridge project aims to connect Bangladesh's principal sea ports and link to the Dhaka-Chittagong Highway. It is estimated that some 30 million people in the region could directly benefit from the new road and rail connection.'

The above are some of the instances of anomalies in the public relation activities and all these are happening as the corporations are somehow related to the corruptions. These practices do not fall in any ethical standard.

\section{Islamic Views of Public Relation}

In Islam the base/benchmark of relationship is 'Satisfaction of Allah (SWT)' and 'Brotherhood'. The foundation is Taqwa - The conscience or fear of Allah - The Almighty. Any one holds Taqwa cannot find himself or herself indulging in things forbidden by Allah (SWT). Following verse from the Quran testify that the harmonious relationship among everyone is possible by inserting the true

Copyright (C) 2013, Asian Business Consortium | ABR sense of Taqwa in one's inner self:

"O mankind! We have created you from a male and a female, and made you into nations and tribes, that you may know one another. Verily, the most honorable of you with Allah is that (believer) who has Taqwa. Verily, Allah is All-Knowing, AllAware." [Qur'an Chapter 49, Verse 13]

Prophet Muhammad (Peace be Upon Him) said, "The most common thing which leads people to Paradise is Taqwa of Allah and good conduct, and the most common thing which leads people to the Hell Fire is the mouth and the private parts." [Tirmidhi]

As mentioned earlier the standard of our relationship is 'Love of Allah'. A legendary Islamic Scholar Ibn Taimiya said, "The declaration of faith, there is no god but Allah, requires you to love only for the sake of Allah, to hate only for the sake of Allah, to ally yourself only for the sake of Allah, to declare enmity only for the sake of Allah; it requires you to love what Allah loves and to hate what Allah hates." [Ibn Taimiya, al-Ihtijaj bil-Qadar, p.62.]

In the life of a human being both 'Friendship' and the 'Enmity' are influential. So, it has become much rational from the part of Islam to set its standards. Enmity for the sake of Allah means giving up all those are restricted or forbidden by Allah; or not to make relations which those who have become derailed by the deception of Devil who have evoked the anger of Allah and who are astray.

An important aspect of Public Relation is keeping the promise. In Islam it has been given the utmost importance. In the Qur'an it has been said that: "And those who break the covenant of Allah after its confirmation and cut asunder that which Allah has ordered to be joined and make mischief in the land; (as for) those, upon them shall be curse and they shall have the evil (issue) of the abode." (Chapter 13, Verse 25).

In Islam, there had a lot of instances of public relations. Usman Ibn Affan (Rd.) - The third successor of Prophet Muhammad (Peace be upon Him) was known as the leader of the faithful. He ruled approximately 12 years as the $3^{\text {rd }}$ Khaliph of Islamic states. Uthman (Rd.) gain intricate knowledge of Islam and built an intimacy with Prophet Muhammad (Peace be upon Him). Uthman (Rd.) gradually became a reference point for those trying to learn Islam and its instruction on different academic and practical issues. There was scarcity of water in Medina. The control of wells was very tight under a few men. Uthman (Rd.) procured and took the control of one well. It was an arrangement with another person that Uthman (Rd.) will use the well for one day and another owner would use the next day. The price was also half and half. Uthman dedicated his well for the Muslims and served water free of charge. Finally Uthman (Rd.) bought the whole well for a fair price and he continued to allow the water to be used freely by all and never reminded the people of his charity.

40 | P a g e 
Not only had that he had a lot of example of his charity, modesty and tranquility. When Muslim forces under the leadership of Prophet Muhammad (Peace be upon Him) started for fighting against the Byzantines at Tabuk prophet called on the wealthier people to give from their wealth and property to support the soldiers. Uthman (Rd.) presented 200 saddled Camels and 200 ounces of Gold. He also contributed 1,000 dinars. Finally he contributed 900 equipped camels (www.huda.tv) ${ }^{[16]}$.

Actually the Muslim Marketers even in the Muslim majority countries are mostly influenced by Materialism and or capitalism. They have got far away from having instructions from Qur'an and Sunnãh. They are losing concerns of the humane value. Here has been portrayed a model following which the marketers particularly Muslim marketers in this world can move forward with a better public relation to handling or heading of unfavorable rumors against them and can build a strong brand which can benefit the marketers herein and hereafter.

Figure - 2: Foundations-Principles-Results Chain of Islamic Public Relation

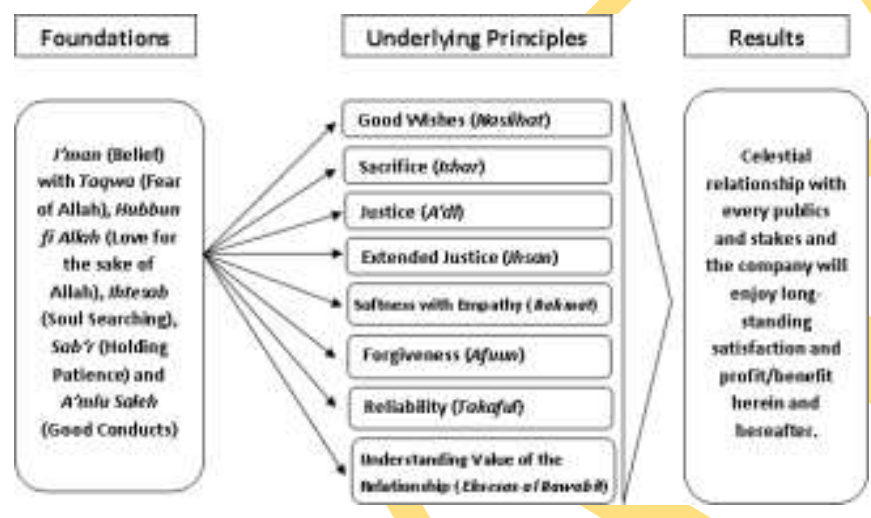

(Source: This figure has been constructed by the author using different Islamic literatures)

The above figure guides the Muslim marketers to hold I'man (Belief) with Taqwa (Fear of Allah), Hubbu Lil Allah (Love for the sake of Allah), Ihtesab (Soul Searching), Sab'r (Holding Patience) and do A'mlu Saleh (Good Conducts) which will saw the seeds of Good wishes for every kind of publics, Sacrifice for them, Justice, Extended Justice, Softness with empathy, Forgiveness, Reliability, and conception of values. The ultimate results are favorable public relations and success herein and hereafter.

\section{Conclusion}

In conclusion it can be said that Islam is complete code of life which is quite capable of guiding our every aspects of life. Allah (SWT) has encouraged us to do business and forbidden us to discard Interest or Usury from our trade and transactions. Qur'an says: 'But Allah has permitted trade and has forbidden interest. (Qur'an: Chapter 2, Verse
275) ' Allah has said to be just and kind to relatives, colleagues, and neighbors. He says, 'And when [other] relatives and orphans and the needy are present at the [time of] division, then provide for them [something] out of the estate and speak to them words of appropriate kindness. (Qur'an: Chapter 4, Verse 8) ' In Bangladesh many companies are doing fraud and deceiving publics of different kinds, sometimes the public particularly government public betray with the companies. But there also have companies which are trying to comply with the Islamic code of Ethics. It's really unfortunate when Muslim marketers do not comply with Islamic ethical standards. If they follow the model suggested and come back to the origin the business environment in Bangladesh will be a split of paradise In sha Allah. However, researchers have the opportunity to work on more issues of Marketing. It can be extended and worked with another tool from Promotion Mix like work can be done on Advertising.

\section{REFERENCES}

[1] Abuznaid, S.A. (2009), "Business ethics in Islam: the glaring gap in practice", International Journal of Islamic and Middle Eastern Finance and Management, Vol. 2 Iss: 4 pp. $278-288$.

[2] Cherrington, J.O. and Cherrington, D.J. (1995), Ethical Decision Making, MicroMash, Englewood, CO

[3] Yusuf, J.B. (2010). "Ethical Implications of Sales Promotion in Ghana: Islamic Perspective", Journal of Islamic Marketing, Vol. 1 Iss: 3 pp. $220-230$.

[4] Murad, K.J. (2003), Islami Andoloner Kormider Paroshporik Somporko, Islami Chhatra Shibir Prokashoni, Bangladesh, p. 3.

[5] Kotler, P. and Keller, K.L. (2005), Marketing Management, Prentice - Hall of India, New Delhi, ed: 12, pp. $19-20$.

[6] Kotler, P. and Armstrong, G. (2011), Principles of Marketing, Prentice - Hall of India, New Delhi, ed: 13, p. 61.

[7] Ibid

[8] Jahan, C.N. (2012), "Anti polythene Act in Bangladesh: A symbolic policy that changes nothing", Dynamics of Public Administration, Vol. 28 Iss: 2 pp. 171 - 187.

[9] Ries, A. and Ries L. (2002), The Fall of Advertising and the Rise of PR, HarperBusiness, New York

[10] Profile of Bangladesh, http://www.indexmundi.com/bangladesh/, Accessed on October 29, 2012

[11] Bhattacharya, D. et al, (2002), "Contribution of the RMG sector to the Bangladesh Economy", CPD Occasional Paper Series 50, Center for Policy Dialogue, Dhaka, Bangladesh, p. 6.

[12] Mahmud, S. and Kabeer, N. (2006), "Compliance Versus Accountability: Struggles for Dignity and Daily Bread in the Bangladesh Garment Industry" The Bangladesh Development Studies, Vol: XXIX, No. 3 and 4, p. $21-46$.

[13] Gardner, K. (2012), "Partnership or PR? Chevron in Bangladesh", http://www.opendemocracy.net/katygardner/partnership-or-pr-chevron-in-bangladesh, Accessed on 30 October, 2012

[14] Hallmark Loan Scam Under ACC Probe, The Daily Star, Tuesday, 14 August 2012 issue, http://www.thedailystar.net/newDesign/newsdetails.php?nid=246119, Accessed on October 30, 2012

[15] World Bank cancels Bangladesh Bridge Loan Over Corruption, http://www.bbc.co.uk/news/world-south-asia-18655846, Accessed on October 30, 2012

[16] Uthman Ibn Affan: Generous and Pious, http:/ / www.huda.tv/articles/miscellaneous-topics/401-uthmanibn-affan-generous-and-pious, Accessed on October 30, 2012.

$$
--0--
$$

